\title{
パルプ機械の研究報告
}

\author{
第 VI \\ パルプ箇の濾過水量の㸴究
}

榎 原 操 吾

現代パルプ工場のパルプ栘 (Pulp Bin)の寸 法には色ஃのものが出來て居る。自然パルプ愿 の厚さ及水切底の面積も色々になる。所が桝の 大切を使命をる洗涤はこの上に水を張つてパル プ層を通し溶出物を流出することである。然る ルパルプ層を通過する水の量は厡の厚さ及水切 底の廣狹に從て違つて來ることは當然である。 それが如何樣に違ふか說明した文献が就ん。

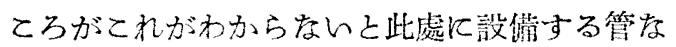
りポンプなりが定められないのである。加ふる にその洗涂效黑为判断するに由ないのである。

筆者は樋口和文氏の協力を得てパルプ愿を樋 過する水量につき琠驗を試みた。その裝監は內 面を旋盤で仕上げを鑄鐵管の底に新しい65目の 製紙用金網をフランヂで締付けて，それにスク

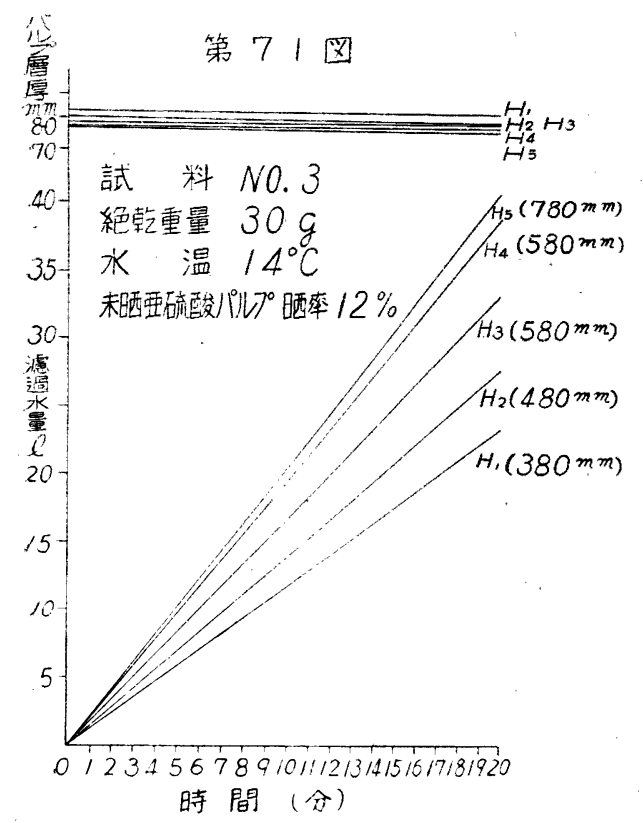

リンで笠分を終つた未唒亞硫酸パルプを入れそ の上に同樣の金網を靜か反乘せた。てれは細い 糸で吊つて分銅で釣合せパルプが亂れないよ5 にし同時にパルプ層の厚さを測るのに利用した。 管の內徑は $102 \mathrm{~mm}$ であつた。水は測定中常に 溢流させて一定の水位を得しめた。斯樣にして 種々のパルプ嬮の厚さと種々の水位につを滤過 水量を測つた。その一例が第71圖と第72圖であ

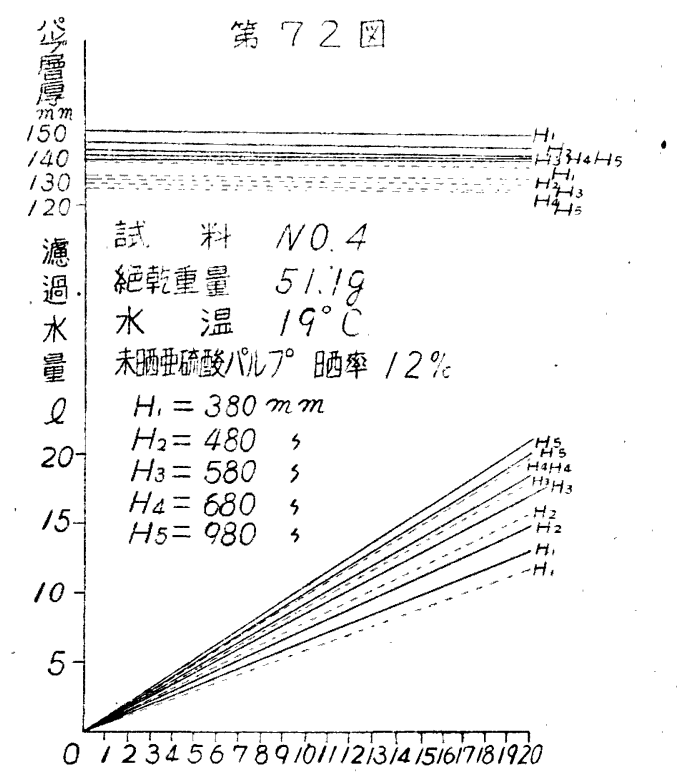

時闃 (分)

る。これを見るとパルプの仕込量が一定（從て パルプ尿の厚さが一定と見做す）であり水位が

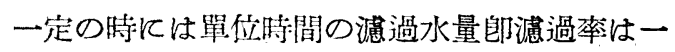
定である。が詹の厚さが粡すと㴓過率が減り水

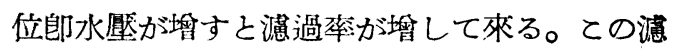
過率とパルプ層の厭さ及水位の關係をまとめる と第26表のよ5になる。パルプ曆の厚さは水位 
が高くなるとパルプが壓縮性なるため多少减少 して來る。そしてパルプ量が多くなると郎厚さ が大きくなるとての變化は段々に大をく反對に パルプ量が少い時は狳り目立たない。その模樣 は第71及72圖に見えて居る。一番變化の多かつ たもので水壓 $380 \mathrm{~mm}$ に於て厚さ $197 \mathrm{~mm}$ のも のが水壓 $780 \mathrm{~mm}$ 亿於て $175 \mathrm{~mm}$ になつた。第 26 表にはその平均を取つて揭げた。貫用上重大 なる結果は生じないと假定して度外視したので ある。實驗中水溫は自然に任せたので $24^{\circ} \mathrm{C} \sim$ $19^{\circ} \mathrm{C}$ に衝いて居る。

各水壓につをパルプ層の厚さと濾過率 $V$ を方 眼紙に點緅すると拋物線のよ5になる。そてで 對數方眼紙に點綴して見ると略平行な直線とな る第73圖がそれである。こてで次のような一般 式に嘗筷らないかと想像してて見る。

$$
V=K H^{n} t^{n}
$$

但 $V=$ パルプ曆の滤滑面積 $1.0 \mathrm{n}^{2}$ につき 1.0 分 閆の滤過水量 $l$

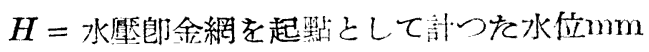

$t=$ パルプ層の厚さ $\mathrm{mm}$

$K=$ 係數

この式で若し $H$ が與へられるならば,

$$
V=c t^{n} \quad c=K H^{m}
$$

$\log V=n \log t+\log c$

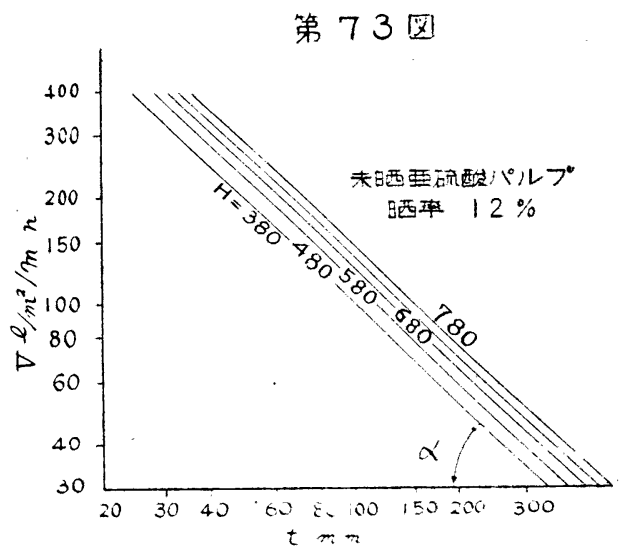

$n$ の值は第73圖から求めるてとが出來る。郎 横軸と直線のなす角 $\alpha$ の $\tan$ である。圖に於け る 5 本の直線は略平行で $5 つ の ~ \alpha$ の值の平均は $44^{\circ} 10^{\prime}$ である。因つて $\tan \alpha=-0.9713$ である。
故江

$$
V=c t^{-0,9713}=K H^{m} t^{-0,9713}
$$

次に $m$ の值を決定せんとして $t=80 \mathrm{~mm}$ に 對し $H$ と $V$ との關係を第 73 圖からとると第 27 表のよ5になる。これを點緅すると第て4圖とな りてれも略直線である。 $t=80$ とすると上の式 は次のようとなる。

$$
V=K H^{m} t^{-0,9713}
$$

$\log V=m \log H+\log K-0.9713 \log 80$

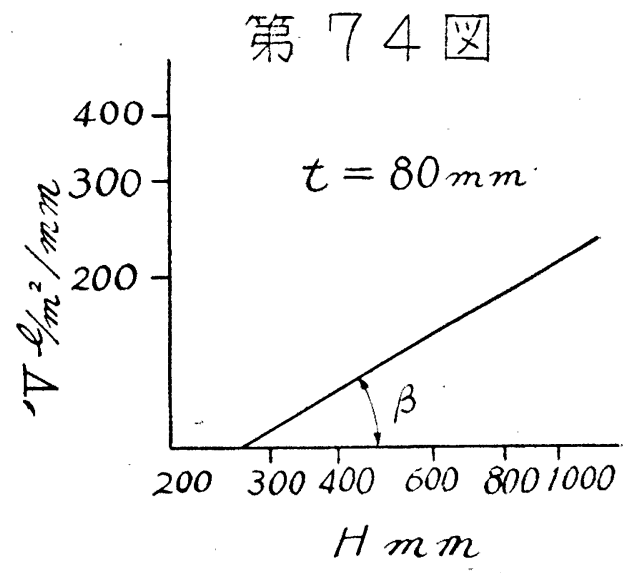

故行第74圖の直線が橫軸とをす㑇 $B$ の $\tan$ は $m$ の僆である。圖で計ると $B=30^{\circ}$ であるか ら $\tan B=m=0.5774$ である。次俰数 $K$ を 決定するため第 74 圖から $H=800 \mathrm{~mm}$ 亿對しV $=190 \mathrm{l} / \mathrm{m}^{2} / \mathrm{mm}$ をとる。とれと $m$ の值を上式 飞當䈤めると

$$
\begin{aligned}
\log 190 & =0.5774 \log 800^{\circ}+\log K \\
& \quad-1.9713 \log 80 \\
\log K & =2.4488 \\
K & =281.2
\end{aligned}
$$

以上で $m n K$ の值が決定したから未晒亞硫酸 パルプに對する濾過率を示す一般式が得られる。 的

$$
V=281 H^{0.58} t^{-0.97}
$$

但ての式は Lews Almy の一般濾過方程式と は根本に相違がある。一般滤過方程式は主とし て磨濾機（Filter Press）を對象としたもので 懸水物が滤布に引掛つて水を放出し濾層が逐次 成長する場合であり，てれは滤層をまづ作りそ れに水を通した場合で丁度淨水に於ける砂滤し 
をパルプでやつたてとになるのである。

溫度が種及汇變つた場合の研究はしてない。 (例)横 $4.5 \mathrm{~m}$ 縱 $23 \mathrm{~m}$ 深さ $3.5 \mathrm{~m}$ のパルプ栘があ つたパルプ層の厚さの. $\mathrm{m}$ 水位は水切底から $2.8 \mathrm{~m}$ 飞保つて洗桬をする際の要水量を計算 する。

$$
\begin{gathered}
V=281 \times 2800^{0.58} \times 2000^{-0.97} \\
\operatorname{lol} V=\log 281+0.58 \log 2800 \\
-0.97 \log 2000 \\
=2.4487+0.55 \times 3.4472 \\
=1.2457 \\
\quad-0.97 \times 3.301 \\
V=17.74 \mathrm{l} / \mathrm{m}^{2} / \mathrm{mn}
\end{gathered}
$$

水切底全面積に對しては

$17.74 \times 4.5 \times 23=1835 \mathrm{l} / \mathrm{mm}(=30.67 / \mathrm{sec})$

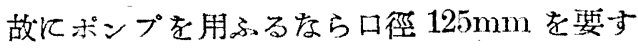
ることを知る。但水張の初期に沬なるべく早 く水を種に被せ度いから 最小限口徑 $150 \mathrm{~mm}$ のポンプを必要とする。
ての計算結果は筆者等の經驗とよく一致する ものであるが，實はパルプ栘の種はチツプの鯭 の形態をなするのがあり離解を終へた種を用ひ て實驗して得た式には嚴正に言へば當筷らない と言へるのであるが，實用して大過なければ先 づよんとして置くのである。

パルプ栘の水張に 2 種の方法が用ひられて居 る。(1)は水を一旦綺麗飞紋り切つて後文水を張 り直す。(2)は水を一旦張つたら種掦を豫想する 時迄連續水を種に被せて置く方法である。洗淮 は水の通過量に比例すると見れば(2)の方法の方 が優れて居ることも勿論である。併し木釜種出 當初は溫度が高いからその谥水を切つた方が松 脂を流すに有效だとか或は廢液を何かと利用す るため種出當初の一回は是非このま〉水切する 必要のある場合は别であるが，その後の水張に 切つたり張つたりするてとは何の意味もない。 そして左榚な作業が未だ各所に行はれてるるの である。

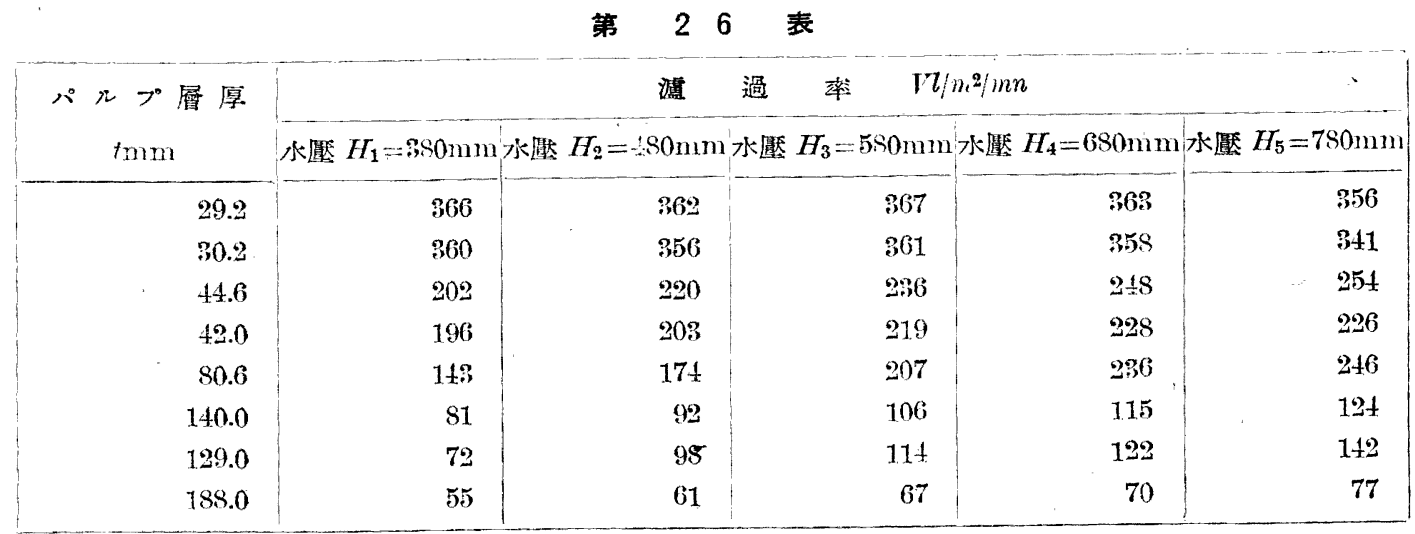

第 27 表

\begin{tabular}{|c|c|}
\hline \multicolumn{2}{|c|}{$t=30 \mathrm{~mm}$} \\
\hline$H \mathrm{~mm}$ & $V l / \mathrm{m}^{2} / \mathrm{mn}$ \\
\hline 380 & 126 \\
480 & 145 \\
580 & 160 \\
680 & 170 \\
780 & 182 \\
\hline
\end{tabular}




\section{ON THE PITCH TROUBLES AT PAPER MILLS AND PRESENT CONDITIONS OF CURING METHODS}

\section{S. Kamei}

After having given the causes and aspects of pitch trouble in various spots at Takasago mill of the Mitsubishi Seishi Co. the writer remarks that the extent of trouble may depend upon the kinds of pulp and paper made from, and suggests such curable methods as seen below :

1. Adding $2 \sim 4 \%$ of bleaching powder in beater and after treating for 2 hours, to make paper without washing.

2. To blend both clay and size in beater after light beating.

On judging from the results of his testing, he says that the chief cause of pitch troubles will lie rather in quality, but not in quantity, and it is judged by the degree of stickiness of pitches in pulp, for which test its tackiness ought to be measured.

He suggests the following temporary methods as being effective for mill practices:

1. For the separation of isolated pitches washing out; dispersing and washing; saponification; salting out in beater; Having on dandy roll sticked, etc.

2. Hardening of soft pitehes.

3. Setting pitches on fiber.

4. Co-operation with pulp makers.

\section{REPORTS ON STUDIES OF PULP MACHINES}

\section{S. Enokibara}

With the data of his empirical tests for the drained quantities of water through various thicknesses of pulp mats and with different hydraulic heads, the writer calculates degree of drainage about unbleached sulphite pulp.

\section{(49頁よりつぶく)}

Tank system タンク式

Total acid 總咥

Thermo-couple 憼胃た心、

Top reliei 占部沓厌しバル

value

Target

Tamming mat

terial

種兴板

なめし.就

Variable spe-

ed motor
タンク式

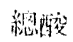

熱莦たい

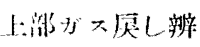

紫利板

なめし㓩

篦速代一ター
Weak lower

Weak-acid

tower

鹏酸塔，第二吸收

掏

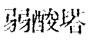

搦酸塔

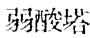

影响解造：

Dislectric:

Constant

Diclectric

density

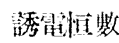

諉筧係数

誘望密埌

誗電宓渡 